\title{
Energy Saving In Heating Systems of Buildings and Structures
}

\author{
Panfilov Stepan Aleksandrovich ${ }^{1}$, Kabanov Oleg Vladimirovich ${ }^{1}$, Shnyakin Ivan Anatolyevich ${ }^{1}$, \\ Valery Fedorovich Danilov ${ }^{2}$, Grigoryev Andrey Anatolievich ${ }^{3}$ \\ ${ }^{1}$ Ogarev Mordovia State University, Russia, Republic of Mordovia, Saransk, 430005, Bolshevitskaya street 68 \\ ${ }^{2}$ Kazan (Volga Region) Federal University, Elabuga Institute, Elabuga, Russia \\ ${ }^{3}$ Associate Professor at the Higher school of physics and materials technology, Institute of mechanical engineering, \\ materials and transport, Peter the Great Saint Petersburg Polytechnic University. 195251 Plytechnicheskaja 29
}

\begin{abstract}
This article is devoted to the description of the integrated management of heating systems of buildings and structures. Integrated control means heating in combination with the control of the ventilation system, as well as a number of auxiliary devices. This makes it possible to implement fullfledged climate control in buildings, taking into account air humidity and temperature indicators in different rooms.
\end{abstract}

Keywords: Climate, Control, System, Construction, Heating, Encoder, Electric Drive, Energy Saving.

\section{INTRODUCTION}

Centralized heating networks that heat modern buildings and structures do not always create comfortable conditions for living and finding a person in the room during working hours. Outside the window, spring or $-25^{\circ} \mathrm{C}$, the temperature of the coolant is often almost the same. And we are forced either to languish in the heat, opening windows and heating the street, or to freeze and use additional heat sources. At the same time paying large bills for the heating season [14]. Properly set heating helps you sleep better as well as feel comfortable. For this, it is necessary that during sleep the temperature of the structure gradually decreases by a couple of degrees from the comfortable temperature [3-24]. Such organizations as Siemens, thebe, salus, viessmann are engaged in the development of heating systems and provide their programs and equipment to the market. The use of automation for the operation of the heating system of buildings and structures is the basic principle for creating comfortable living conditions, as well as for saving not unlimited fuel resources [10, 16, 17].

Having installed energy metering devices, the question naturally arises of how it is possible to regulate and control the supply of the coolant, to limit or reduce its consumption. For this, there are all kinds of automatic regulators, the use of which allows you to save money, they work from outdoor temperature sensors and return pipe sensors. Another advantage of temperature controllers is temperature control directly at the place of installation of the radiator, unlike other devices. This advantage gives priority to obtaining a uniform temperature background for a comfortable stay in the room. The regulator will prevent overheating of the air in the room, which may not always be tracked by the sensors on the centralized automation $[8,18]$. And also it is possible to adjust the temperature for each room separately. Sometimes, when deciding the issue of regulation, ordinary taps are installed. Of course, this solution reduces financial costs, but deprives of a number of useful advantages. The crane has limited opening and closing functionality. There is a danger of stopping or airing the riser. By adjusting the heating with taps, it is impossible to achieve the required temperature regime. Using automatic regulators it is possible to adjust the system accurately and efficiently $[1,12,19]$.

Danfoss motorized control valves (RK and EP) for district heating and cooling, HVAC and central heating systems provide stable and accurate control of the flow of water, glycol solutions and steam. In turn, this optimizes thermal management and increases the reliability and energy efficiency of systems. All of these advantages increase the level of comfort for end users [15,20]. Various sizes, materials of construction and connection options provide versatility in control valves and actuators. They also have a number of different functions and capabilities to suit the requirements of each specific application. For example, the latest Danfoss solutions, which have already gained worldwide recognition for their high quality and reliability, are offered in different price ranges, so you can always find the right options according to the project budget.

\section{I.I Excellent control characteristics}

The regulating ability of the RK and EP series products is due to many characteristics, including combined characteristics for hot water supply systems with heat exchangers, as well as linear and logarithmic characteristics. These devices meet the most stringent control requirements in central heating systems and are capable of providing uninterrupted heat supply. For domestic hot water applications, the low slope of the combined characteristic in this zone of the valve stroke ensures stable valve control in the critical zone near the closed position. On the other hand, the steeper part of the characteristic (high flow rate) ensures fast and reliable regulation [15].

Proven economy throughout the entire service life.

Ease of selection, installation, commissioning and maintenance of products on the example of Danfoss RK and EP series saves time, money and reduces labor costs [15]. 


\section{I.II Easy to install and operate}

Valves of the RK and EP series are easy to operate and maintain. The threaded coupling allows quick connection between the actuator and the valve and also allows rotation after installation. LED indicators help you complete MCV installation and commissioning in less time and with less effort [15]. Increased reliability and a higher level of operational safety These valves have built-in overheating and overload protection for the motor. This greatly reduces the likelihood of failure of the valve or the system as a whole during operation.

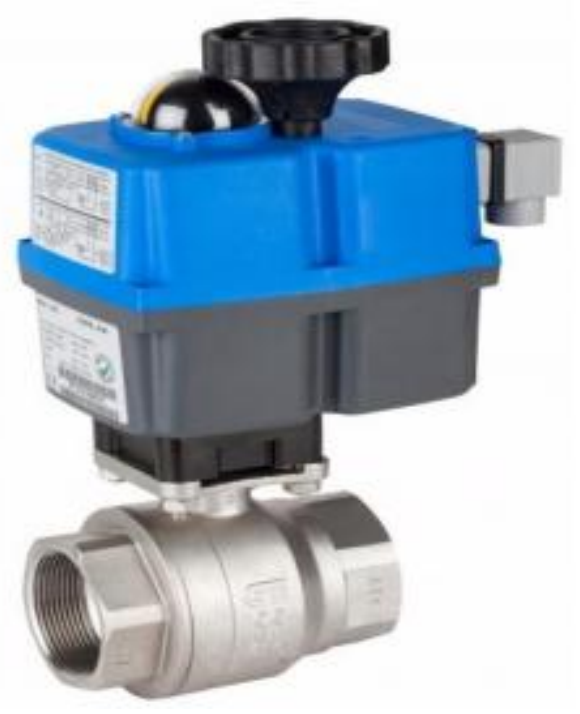

Figure 1. Valve with electric drive

The motorized valve shown in Figure 1 is the most convenient for connecting to centralized heating networks, to automation circuits that heat modern buildings and structures. Any controller with an output relay of the appropriate capacity is suitable for controlling the drive. The main parameters of the electric drive: - voltage; - current; - closing speed. Valves with an electric actuator can be used in buildings and residential buildings in heating systems. These drives can be installed with or without logic controllers to provide complete process automation. The entire structure of the electric drive is assembled in a protective steel casing, which in turn has an outlet to a flange connection with the valve stem [4-7,21]. In addition, gate positioning boards can be mounted in these actuators. To adjust the unified drive, it will be necessary to supplement it with a digital positioning module. This is an inexpensive controller board that will allow the actuator to automatically rotate the gate a certain degree. The positioning module has unified digital buses and connects to conventional controllers. The encoder of the positioning module is the encoder $[13,22]$.

An encoder is a transducer of angular displacements used to modify the angle of rotation of an object of rotation, for example, a shaft of any mechanism, into an electric current signal. In this case, not only the angle of rotation of the shaft is determined, but also its direction of rotation, as well as the speed of rotation and the current position relative to the initial position $[4,9,23]$. Hysteresis and angle determination error - no more than $2 \%$. This accuracy is more than sufficient for most applications. Which in turn will allow us to control the flow rate of the coolant in heat supply systems. Thanks to this, we will control the temperature in the room, and regulate it as needed with the least heat loss. To calculate the flow, use the dependence of the pressure drop on the angle of rotation of the valve. Nowadays it is not difficult to buy a valve with an electric drive. For high-quality operation of a valve with an electric drive, it is necessary to use reliable and durable proven components from the best manufacturers in this field - these are brands such as Vilmann, Gruner, General Climate, Danfoss, Genebre $[3,11,14]$. At the same time, the cost of such a device is low, and the ease of installation only adds to its popularity. By connecting this device to the controller, we can compare the ambient temperature with the room temperature [24-25]. Such a heating system will allow you to quickly respond to the slightest change in temperature in the building. And also saves a lot of money and nerves during the heating season.

\section{REFERENCES}

[1] Anuchin A.S. Electric drive control systems / A.S. Anuchin. - Vologda: InfraEngineering, 2015 .-- 373 p.

[2] Automated electric drive and tracking systems/A.B. Zelenov and others - Moscow: Gostekhizdat, 1990.-$360 \mathrm{p}$.

[3] Arkhipov V. Systems for the "intelligent" building / V. Arkhipov // Stroy Market, 2007. - 45 p.

[4] Anuchin A.S. Electric drive control systems / A.S. Anuchin. - Vologda: InfraEngineering, 2015 .-- 373 p.

[5] Belov M.P. Automated electric drive of standard production mechanisms and technological complexes: Textbook. for universities / M.P. Belov, V.A. Novikov, L.N. Rassudov. - M .: Ed. Center "Academy", 2004. $578 \mathrm{p}$.

[6] Gopal K. Dubey Basic principles of the device of electric drives / Gopal K. Dubey. - Moscow: Mechanical Engineering, 2009 .-- 480 p.

[7] Engineering of electric drives and automation systems: textbook. manual for stud. higher. study. institutions / [Belov, O.I. Zementov, A.E. Kozyaruk and others]; ed. V.A. Novikova, L.M. Chernigov. - M .: Publishing Center "Academy", 2006. - 368 p.

[8] Kabanov OV Problems of construction of technical means of energy saving / OV Kabanov, SA Panfilov // Problems and prospects of development of domestic lighting technology, electronics and energy. XIII Int. scientific and technical conf. - Saransk, 2017 .-- 557 p.

[9] Klyuchev V.I. Electric drive and automation of general industrial mechanisms: Textbook. for universities / V.I. Klyuchev, V.M. Terekhov. - M .: Energiya, 1980 .-$358 \mathrm{p}$.

[10] Krylov Yu.A. Energy saving and automation of production in the heat and power sector of the city. Frequency-controlled electric drive: Textbook / Yu.A. 
Krylov, A.S. V. N. Karandaev Medvedev. - SPb .: Lan, 2013 --- 176 p.

[11] Moskalenko V. V. Automated control systems for electric drives / V.V. Moskalenko. - Moscow: Higher school, 2013 .-- 208 p.

[12] Sumrin Yu. P. Theory of systems and system analysis: textbook. allowance / Yu. P. Sumrin. - K .: MAUP, 2006 .-- 368 p.

[13] Pipeline fittings with automatic control: Handbook / D. F. Gurevich, O. N. Zarinsky, S. I. Kosykh and others; Under total. ed. S. I. Kosykh. - L .: Mechanical engineering, Leningrad. department, 1982 .-- 320 p.

[14] Yumaeva D. R. Smart technologies for your home / D. R. Yumaeva, R. R. Yumaeva. - 2014 .-- S. 21-22.

[15] Motorized control valves. Electronic resource. Date of access (28.09.2020.) Https://www.danfoss.com/ru$\mathrm{ru} /$ products/differential-pressure-and-flowcontrollers/dhs/motorized-control-valves-andactuators/\#tab-overview

[16] Vladimirovich, K. O., Aleksandrovich, P. S., Alexandrovich, P. A., \& Sergeevna, S. E. (2019). Measuring the thermo physical properties of construction projects. Journal of Computational and Theoretical Nanoscience, 16(7), 3121-3127. doi:10.1166/jetn.2019.8229

[17] Vladimirovich, K. O., Aleksandrovich, P. S., Alexandrovich, P. A., \& Sergeevna, S. E. (2019). Automated portable installation to determine the thermo physical properties of the object. Journal of Computational and Theoretical Nanoscience, 16(7), 3115-3120. doi:10.1166/jctn.2019.8228

[18] Vladimirovna, L. A., Vladimirovich, K. O., \& Mordovia, O. (2019). Energy-efficient autonomous system of heating. Journal of Computational and Theoretical Nanoscience, 16(1), 145-150. doi:10.1166/jctn.2019.7714

[19] Vladimirovna, L. A., Vladimirovich, K. O., \& Viktorovich, M. V. (2019). Conducting audits in small enterprises and assessing their compliance with international standards. Journal of Critical Reviews, 6(4), 79-83. doi:10.22159/jcr.06.04.14

[20] Sergeevna, S. E., Vladimirovich, K. O., Anatolievich, G. A., Ivanovich, P. K., Vladimirovich, U. A., Valentinovich, N. A., . . Gennadievna, V. E. (2020). Features of the use of testing as a method of pedagogical control of students' knowledge in the educational process. Journal of Critical Reviews, 7(3), 181-184. doi:10.31838/jcr.07.03.33

[21] Vladimirovich, K. O., Evgenievna, S. J., Nikolaevich, Z. V., Anatolevich, R. D., Anatolievna, K. I., Vasilievna, K. A., . . . Alexandrovich, M. S. (2020). Visualization of information in the educational process: Current trends. Systematic Reviews in Pharmacy, 11(4), 1-5. doi:10.31838/srp.2020.4.01

[22] Vladimirovich, K. O., Evgenievna, S. J., Nicolaevna, N. L., Borisovna, Y. T., Sergeevich, G. A., Ivanovna, T. I., \& Ivanovich, P. V. (2020). Digital economy and logistics as new areas of study in higher education. [Economía digital y logística como nuevas áreas de estudio en educación superior] Opcion, 36(SpecialEdition26), 1194-1211.

[23] Ivanovich, P. V., Vladimirovich, K. O., Anatolievich, G. A., Sergeevich, G. A., Ivanovich, S. V., Nashatovna, M. V., \& Vladimirovna, Y. N. (2020). Digital literacy and digital didactics for the development of new learning models. [Alfabetización digital y didáctica digital para el desarrollo de nuevos modelos de aprendizaje] Opcion, 36(Special Edition 27), 13571376. Retrieved from www.scopus.com

[24] Sergeevna, S. E., Vladimirovich, K. O., Nikolaevna, E. M., Chandra, R., Aleksandrovich, G. S., \& Markaryan, V. R. (2020). The role of investments for the economy of the russian federation. [El papel de las inversiones para la economía de la federación de rusia] Opcion, 36(SpecialEdition27), 1377-1385. Retrieved from www.scopus.com

[25] Vladimirovich, K. O., Alexandrovich, P. S., Anatolievich, V. E., Ivanovich, A. A., Anatolievich, G. A., \& Mikhailovich, P. Y. (2020). Main nuances of the selection of a gas boiler for a heat supply system. Journal of Advanced Research in Dynamical and Control Systems, 12(5 Special Issue), 1487-1489. doi:10.5373/JARDCS/V12SP5/20201910 